\title{
Factors That Affect Sleep Quality in Hospitalized Patients with COVID-19 Pneumonia
}

\section{COVID-19 Pnömonisi ile Hastanede Yatan Hastalarda Uyku Kalitesini Etkileyen Faktörler}

\author{
(D) Özge Oral Tapan, (D) Utku Tapan, (D) Fatih Alasan, (D) Ayşe Ferhan Akgül*, (D) Sebahat Genç \\ Muğla Sıtkı Koçman University Faculty of Medicine, Department of Chest Diseases, Muğla, Turkey \\ *Muğla Sıtkı Koçman University Faculty of Medicine Department of Infectious Diseases, Muğla, Turkey
}

\begin{abstract}
Objective: Sleep is important for metabolism and the immune system. Disturbed sleep may be a risk factor for poor recovery from diseases. Coronavirus disease-2019 (COVID-19) pneumonia has been the most common cause of hospitalization in the last year. This study aimed to evaluate the sleep quality of hospitalized patients with COVID-19 pneumonia and the factors that affect their sleep quality.

Materials and Methods: This cross-sectional study included patients with COVID-19 pneumonia who were hospitalized at a pandemic clinic. The demographic data, symptoms, laboratory parameters, and hospitalization duration were evaluated. After the first night of admission, the patients completed Pittsburgh sleep quality index (PSQI) and hospital anxiety and depression scale (HADS).

Results: This study included 105 patients, of whom 55 were with mild-moderate pneumonia and 50 with severe pneumonia. The mean value of the total PSQI score was $8.43 \pm 2.03$ in the non-severe group and $12.64 \pm 2.24$ in the severe group. Positive correlations were found between the total PSQI score and age, HAD-A score, HAD-D score, length of hospital stay, and ferritin. Negatively significant correlations were found between the PSQI score and leukocyte count, lymphocyte count, albumin, and oxygen saturation. Independent factors, such as disease severity, HADS scores, oxygen saturation, and dyspnea, were associated with the total PSQI score $\left(R^{2}=0.630\right)$.

Conclusion: Patients who are hospitalized with COVID-19 pneumonia had poor sleep quality. Sleep quality was affected by disease severity. Anxiety and depression levels, oxygen saturation, and dyspnea are associated with sleep quality in these patients.

Keywords: COVID-19 pneumonia, sleep quality, anxiety, depression, hospitalization
\end{abstract}

\section{Introduction}

Sleep is very important for the maintenance of both physiological and psychological well-being of the individual. Sleep is a form of rest that can be interrupted by stimuli of different degrees
Öz

Amaç: Uyku, metabolizma ve bağışıklık sistemi için önemlidir. Kötü uyku, hastalıkların zayıf iyileşmesi için bir risk faktörü olabilir. Koronavirüs hastalı̆̆ı-2019 (COVID-19) pnömonisi son bir yılda en sık hastaneye yatış nedeni olan enfeksiyondur. Bu çalışmanın amacı, hastanede yatan COVID-19 pnömonili hastaların uyku kalitesini değerlendirmek ve etkileyen faktörleri belirlemektir.

Gereç ve Yöntem: Çalışmamız, pandemi kliniğinde yatan COVID-19 pnömonili hastaları içeren kesitsel bir çalışmadır. Demografik veriler, semptomlar, enflamasyon belirteçleri, hastanede kalış süresi, anksiyete ve depresyon durumu değerlendirilmiştir. Katılımcılara, hastaneye yatışlarının ertesi gününde Pittsburgh uyku kalitesi indeksi (PUKI) ve hastane anksiyete ve depresyon ölçeği (HADS) uygulanmıştır.

Bulgular: Çalışmaya 105 gönüllü hasta dahil edildi. Elli beşi hafif-orta pnömonili, 50'si ağır pnömonili hastalardı. Toplam PUKí puanının ortalama değeri şiddetli olmayan grupta $8,43 \pm 2,03$, şiddetli grupta $12,64 \pm 2,24$ olarak saptandı. Toplam PUKI puanı ile yaş, HAD-A skoru, HAD-D skoru, hastanede yatış süresi ve ferritin arasında pozitif yönde; lökosit sayısı, lenfosit sayısı, albümin ve oksijen satürasyonu arasında negatif yönde anlamlı korelasyon bulundu. Hastalık şiddetinin, HADS skorlarının, oksijen satürasyonunun ve dispnenin, toplam PUKI puanını etkilediği saptandı $\left(R^{2}=0,630\right)$.

Sonuç: COVID-19 pnömonisi ile hastaneye yatırılan hastaların uyku kalitesi kötüdür. Uyku kalitesi hastalık şiddetinden etkilenmektedir. Bu hastalarda anksiyete ve depresyon düzeyleri, oksijen satürasyonu ve dispne uyku kalitesi ile ilişkilidir.

Anahtar Kelimeler: COVID-19 pnömonisi, uyku kalitesi, anksiyete, depresyon, hospitalizasyon

and creates changes in the state of consciousness and is also a necessity for a healthy and long life where the body renews itself (1). Sleep-wake cycle of hospitalized patients is variable. Their circadian rhythms are disrupted. Sick individuals have

Address for Correspondence/Yazışma Adresi: Özge Oral Tapan MD, Muğla Sıtkı Koçman University Faculty of Medicine, Department of Chest Diseases, Muğla, Turkey Phone: +90252 2115244 E-mail: ozgeeoral@hotmail.com ORCID-ID: orcid.org/0000-0003-1499-3747 Received/Geliş Tarihi: 03.06.2021 Accepted/Kabul Tarihi: 23.08.2021

${ }^{\circ}$ Copyright 2022 by Turkish Sleep Medicine Society / Journal of Turkish Sleep Medicine published by Galenos Publishing House. 
decreased sleep quality which adversely affecting their illness and health conditions (2). An association has been reported between sleep quality of hospitalized patients and functional improvement during the first 3 months after discharge and increased mortality risk within a year $(3,4)$. Sleep disturbance may be a risk factor for late recovering from hospitalizations (5) or prolonged hospital stay depending on the severity of the disease may impair sleep quality.

Millions of people have been affected by the Coronavirus disease-2019 (COVID-19) that was caused by the severe acute respiratory syndrome-coronavirus-2. It has been shown that the novel infectious diseases, such as severe acute respiratory syndrome have effects on sleep by increasing anxiety, depression, and stress levels in the general population (6).

The Pittsburgh sleep quality index (PSQI) is a well-known questionnaire to determine sleep disturbances in adults (7). PSQI is commonly used for monitoring the sleep over the past one month. The hospital anxiety and depression scale (HADS) is a self-assessment scale that was developed for determining the risk of anxiety and depression in patients with somatic diseases (8).

There are some typically changes in laboratory parameters of patients with COVID-19 pneumonia. Inflamatory markers such as C-reactive protein (CRP), procalcitonin and serum ferritin, haematological parameters such as white blood cell (WBC) count, lymphocyte count and coagulation markers such as D-dimer have been associated with the disease severity and prognosis (9).

Sleep impairment was reported frequent in patients with COVID19 (10), that may be due to isolation, physical discomfort, and psychological factors such as fear, anxiety or depression (11). Poor sleep quality during hospitalization in COVID-19 patients was reported as associated with a slow recovery from lymphopenia and an increased need for intensive care (12).

The aim of this study was to evaluate the sleep quality and the factors affecting the sleep quality of hospitalized patients with COVID-19 pneumonia.

\section{Materials and Methods}

This study was performed in accordance with the Declaration of Helsinki and was approved by the Muğla Sıtkı Koçman University Human Research Ethics Committee (protocol number: 200179, decision no: 150). All patients provided signed informed consent to participate in the study.

Patients with COVID-19 pneumonia who were hospitalized at pandemic clinic of Muğla Sıtkı Koçman University Education and Training Hospital between 15 July-15 October 2020 were included. Adult patients over the age of 18 who had accepted to participate in were enrolled to the study. The patients who had any diagnosed sleep related disorders, neurological and psychiatric diseases were excluded. This is a cross-sectional study. The demographic data (age, gender, occupation, smoking, comorbidity, body mass index), symptoms, laboratory parameters within $24 \mathrm{~h}$ of admission and length of hospitalization stay were recorded. The patients completed PSQI and HADS after the first night of admission for minimalizing the hospital factors (e.g., light exposure, sound exposure, and disturbance by staff) that could be the reason of poor sleep quality during hospitalization.

The questionnaires were performed face to face in patients' room. Clinicians wore personel protective equipments and the patients wore surgical masks during the survey which took maximum 15 minutes.

The PSQI questionnaire that consisted of seven parts a total of 18 items, including sleep quality, sleep duration, sleep latency, habitual sleep efficiency, sleep disturbances, use of sleeping medications, and daytime dysfunction was used to measure the sleep quality of the patients. Each part was scored from 0-3, and the total score ranged from 0-21. A high score is accepted as indicating poor sleep quality (13).

The HADS translated to Turkish, validity and reliability study has been done (14). It has anxiety (HAD-A) and depression (HAD-D) subscales. Totally contains 14 questions. Seven of them (odd numbers) measures anxiety and the other seven (even numbers) measures depression. It provides a quadruple Likert type measurement. According to the results of the study performed in Turkey, the subscale cut-off score for anxiety was $10 / 11$, the subscale cut-off score for depression was $7 / 8$. The scores above these are considered as risk group. The lowest score can be obtained from both subscales is 0 , while the highest score is 21 .

\section{Statistical Analysis}

Data analysis was done by the SPSS program version 23.0. The sample sizes required for independent sample t-test and chi-square tests by using the G-Power software at medium effect size. Patients with COVID-19 pneumonia were divided into two groups. Patients who had the value of $\mathrm{SpO}_{2}$ under $94 \%$ on room air, a ratio of arterial partial pressure of oxygen to fraction of inspired oxygen $\left(\mathrm{PaO}_{2} / \mathrm{FiO}_{2}\right)$ below $300 \mathrm{~mm}$ $\mathrm{Hg}$, respiratory frequency over 30 breaths per minute, or lung infiltrates more than 50\% were considered as severe. Individuals who had any of the various signs and symptoms of COVID-19 (e.g., fever, cough, sore throat, malaise, headache, muscle pain, nausea, vomiting, diarrhea, loss of taste and smell), dyspnea, or abnormal chest imaging with the value of $\mathrm{SpO}_{2}$ over $94 \%$ considered as non-severe.

Descriptive statistics in the form frequencies and percentages were used to describe the demographics. Means and standard deviations (mean \pm standard deviation) were analyzed by a t-test if the data showed normally distribution) and MannWhitney $U$ test. Chi-square test was used for categorical data. The relationships between parameters were calculated with correlation coefficient. Normally distributed data were calculated with the Pearson Correlation Coefficient, Spearman Rank Correlation was used to calculate the data that did not show normal distribution. To determine the factors affecting sleep quality in 105 patients with COVID-19 pneumonia, the relationship between total PSQI score and the other parameters was examined. Logistic regression analysis was used to identify parameters that affect PSQI. $\mathrm{P}<0.05$ was accepted as the level of significance. 


\section{Results}

One hundred-five individuals from the patients, who were treated at the covid ward in Muğla Sıtkı Koçman University Training and Research Hospital during the period of 15 July 2020 to 15 October 2020, agreed to participate in the study. Fifty-five of the patients had non-severe COVID-19 pneumonia, 50 of the patients had severe COVID-19 pneumonia. The demographic data of the participants is shown in Table 1. Patients with non-severe COVID-19 pneumonia were younger than the patients with severe infection. The number of male individuals were higher in patients with severe COVID-19 pneumonia. Alcohol use and hypertension were more common in the severe group. Dyspnea and gastrointestinal symptoms such as diarrhea and abdominal pain were more frequent in the severe COVID-19 pneumonia whereas anosmia was more frequent in the non-severe group. The clinical features of the patients are summarized in Table 1. HAD-A and HAD-D scores in patients with severe COVID-19 pneumonia were significantly higher than the non-severe group (Table 2). The total PSQI questionnaire score of the study patients was $10.43 \pm 2.99$ (6.00$17.00)$ and it was was significantly higher in the severe patients. The comparison of sub-scales of the PSQI questionnaire were shown in Table 2. Laboratory parameters associated with inflammation and coagulation were higher whereas the WBC and lymphocyte counts and albumin were lower in nonsevere COVID-19 pneumonia patients (Table 3). The total PSQI score of the patients with COVID-19 pneumonia had positive correlations with both HAD-A and HAD-D scores. There were significant correlations between total PSQI score and age, hospitalization day and ferritin. There were significant negative correlations between total PSQI score and WBC, lymphocyte, albumin and oxygen saturation. However, total PSQI score had no significant correlations between age, body mass index (BMI), comorbidity, smoking. Correlations between total PSQI score and factors affecting sleep quality are summarized in Table 4. Total PSQI score was significantly associated with HAD-A, HAD$D$, oxygen saturation, hospitalization time, disease severity and dyspnea $\left(R^{2}=0.630\right)$. Multiple regression analysis results were shown in Table 5.

\section{Discussion}

In our study, the sleep quality of patients hospitalized with COVID-19 was poor. Hospital depression and anxiety scores of the patients with COVID-19 pneumonia were high. We found that the disease severity, hospitalization days, dyspnea, oxygen saturation, hospital depression and anxiety scores affect the sleep quality of these patients significantly. WBC, lymphocyte, albumin and ferritin levels were significantly related with the total PSQI score.

PSQI is a reliable and consistent survey, it is used in many patient groups. Having a PSQI global score of 5 or above indicates poor sleep quality as shown in several studies $(15,16)$. Since the mean value of total PSQI score 10.43 \pm 2.99 in our study, we thought that our patients hospitalized with COVID-19 pneumonia had poor sleep quality. The low values of sleep duration subscales (PSQI 2) and sleep latency (PSQI 3) may be determined as results of the disease severity.

\begin{tabular}{|c|c|c|c|}
\hline & \begin{tabular}{|l|}
$\begin{array}{l}\text { Non-severe } \\
(\mathrm{n}=55)\end{array}$ \\
\end{tabular} & $\begin{array}{l}\text { Severe } \\
(\mathrm{n}=50)\end{array}$ & $p$ \\
\hline Age (years) & $45.65 \pm 16.31$ & $51.42 \pm 13.01$ & 0.049 \\
\hline Gender (female/male) (n) & $38 / 17$ & $21 / 29$ & 0.005 \\
\hline Marital status (married/single) (n) & $39 / 16$ & $43 / 7$ & 0.062 \\
\hline BMI $\left(\mathrm{kg} / \mathrm{m}^{2}\right)$ & $26.17 \pm 3.70$ & $26.24 \pm 2.62$ & 0.918 \\
\hline Smoking (yes/no) (n) & $22 / 33$ & $25 / 25$ & 0.303 \\
\hline Smoking pack-years & $8.49 \pm 12.67$ & $11.66 \pm 13.35$ & 0.294 \\
\hline Comorbidity (yes/no) (n) & $22 / 33$ & $25 / 25$ & 0.303 \\
\hline HT (yes/no) & $10 / 45$ & $18 / 32$ & 0.039 \\
\hline DM (yes/no) & $8 / 47$ & 9/41 & 0.631 \\
\hline CAD (yes/no) & $4 / 51$ & $5 / 45$ & 0.618 \\
\hline COPD (yes/no) & $4 / 51$ & $6 / 44$ & 0.410 \\
\hline Asthma (yes/no) & $5 / 50$ & $10 / 40$ & 0.111 \\
\hline Fever (yes/no) & $44 / 11$ & $45 / 5$ & 0.154 \\
\hline Cough (yes/no) & $43 / 12$ & $44 / 6$ & 0.182 \\
\hline Dyspnea (yes/no) & $17 / 38$ & $47 / 3$ & $<0.001$ \\
\hline Anosmia (yes/no) & $13 / 42$ & $4 / 46$ & 0.002 \\
\hline GIS symptoms (yes/no) & $9 / 37$ & $11 / 29$ & 0.030 \\
\hline Myalgia (yes/no) & $35 / 20$ & $32 / 18$ & 0.969 \\
\hline Hospitalization day (n) & $7.32 \pm 2.53$ & $16.92 \pm 5.12$ & $<0.001$ \\
\hline
\end{tabular}




\begin{tabular}{|c|c|c|c|}
\hline & $\begin{array}{l}\text { Non-severe } \\
(n=55)\end{array}$ & $\begin{array}{l}\text { Severe } \\
(n=50)\end{array}$ & $\mathbf{p}$ \\
\hline Sleep quality & $1.3 \pm 0.6$ & $2.8 \pm 0.6$ & $<0.001$ \\
\hline Sleep duration & $2.5 \pm 0.7$ & $2.1 \pm 0.7$ & $<0.001$ \\
\hline Sleep latency & $2.7 \pm 0.5$ & $2.4 \pm 0.6$ & 0.003 \\
\hline Habitual sleep efficiency & $0.2 \pm 0.7$ & $1.8 \pm 0.8$ & 0.026 \\
\hline Sleep disturbances & $1.3 \pm 0.7$ & $2.2 \pm 0.7$ & $<0.001$ \\
\hline Use of sleeping medications & $0.02 \pm 0.1$ & $0.4 \pm 0.5$ & $<0.001$ \\
\hline Daytime dysfunction & $0.4 \pm 0.7$ & $1.4 \pm 1.0$ & $<0.001$ \\
\hline PSQI total & $8.43 \pm 2.03$ & $12.64 \pm 2.24$ & $<0.001$ \\
\hline HAD-A & $8.01 \pm 3.38$ & $13.18 \pm 3.53$ & $<0.001$ \\
\hline HAD-D & $9.00 \pm 3.29$ & $11.76 \pm 3.70$ & $<0.001$ \\
\hline
\end{tabular}

\begin{tabular}{|c|c|c|c|}
\hline & $\begin{array}{l}\begin{array}{l}\text { Non-severe } \\
(\mathrm{n}=55)\end{array} \\
\end{array}$ & $\begin{array}{l}\text { Severe } \\
(n=50)\end{array}$ & $p$ \\
\hline WBC (mcL) & $5.57 \pm 2.51$ & $8.20 \pm 4.68$ & 0.003 \\
\hline Lymphocyte (mcL) & $1.48 \pm 0.67$ & $0.96 \pm 0.59$ & $<0.001$ \\
\hline D-dimer (ng/mL) & $486.21 \pm 935.37$ & $604.77 \pm 669.28$ & 0.096 \\
\hline Ferritin $(\mathrm{mL} / \mathrm{ng})$ & $203.46 \pm 213.66$ & $683.97 \pm 746.64$ & $<0.001$ \\
\hline CRP (mg/L) & $21.73 \pm 35.10$ & $78.82 \pm 95.65$ & 0.003 \\
\hline Procalcitonin (ng/mL) & $0.08 \pm 0.07$ & $1.42 \pm 6.64$ & 0.005 \\
\hline Albumin (g/dL) & $40.24 \pm 4.78$ & $36.27 \pm 5.69$ & $<0.001$ \\
\hline
\end{tabular}

Table 4. Correlations between PSQI and factors affecting sleep quality

\begin{tabular}{|c|c|c|c|c|c|c|c|c|c|c|c|}
\hline \multirow{3}{*}{$\begin{array}{l}\text { Spearman's } \\
\text { Rho }\end{array}$} & & & Age & HAD-A & HAD-D & Hospitalization day & WBC & LYM & Alb & Ferr & $\mathrm{SpO}_{2}$ \\
\hline & PSQI & $r$ & 0.268 & 0.552 & 0.402 & 0.515 & -0.242 & -0.303 & -0.311 & 0.269 & -0.622 \\
\hline & & $\mathrm{p}$ & 0.007 & $<0.001$ & $<0.001$ & $<0.001$ & 0.015 & 0.001 & 0.002 & 0.007 & $<0.001$ \\
\hline
\end{tabular}

PSQI: Pittsburgh sleep quality index, HAD-A: Hospital anxiety and depression-anxiety, HAD-D: Hospital anxiety and depression-depression, WBC: White blood cells, LYM: Lymphocyte, Alb: Albumine, Ferr: Ferritin, $\mathrm{SpO}_{2}$ : Oxygen saturation

\begin{tabular}{|c|c|c|c|c|c|c|c|}
\hline \multirow{2}{*}{ Variable } & \multicolumn{2}{|c|}{ Unstandardized } & \multicolumn{2}{|l|}{$95 \% \mathrm{Cl}$ for $\mathrm{B}$} & \multicolumn{2}{|c|}{ Standardized } & \multirow{2}{*}{$p$} \\
\hline & B & SE & Lower limit & Upper limit & $\beta$ & $\mathbf{t}$ & \\
\hline HAD-A & 0.153 & 0.074 & 0.006 & 0.301 & 0.221 & 2.062 & 0.042 \\
\hline HAD-D & 0.158 & 0.077 & 0.006 & 0.311 & 0.198 & 2.060 & 0.042 \\
\hline $\mathrm{SpO}_{2}$ & -0.332 & 0.081 & -0.494 & -0.171 & -0.448 & -4.080 & $<0.001$ \\
\hline Hospitalization day & 0.161 & 0.044 & 0.073 & 0.249 & 0.336 & 3.640 & $<0.001$ \\
\hline Disease severity & 4.356 & 0.446 & 3.471 & 5.242 & 0.730 & 9.762 & $<0.001$ \\
\hline Dyspnea & -3.058 & 0.550 & -4.150 & -1.967 & -0.500 & -5.560 & $<0.001$ \\
\hline
\end{tabular}

Decreased sleep time due to being sick and the change of sleep environment as a result of hospitalization can affect sleep wake cycle and causes daytime somnolence (17). In several studies, poor sleep quality was frequently observed in hospitalized patients (18). Sleep disorders may occur in patients with COVID-19 (10). Isolated environment, physical discomfort, or emotions (fear, anxiety and/or depression, etc.) may the responsible risk factors (11). In a study, strong relationship between evening electronic device usage during the lockdown period and sleep disturbances has been shown 
(19). It has been reported that poor sleep quality impairs emotional regulation and increases affective reactivity (20) and it is associated with increased negative emotions (21). Poor sleep quality has been associated with stress, depression and anxiety during the COVID-19 pandemic in the general population (22). It was found that as the severity of the disease increased, the anxiety and depression scales increased. This may depend on the stress factors about the COVID-19 infection. Stress has shown to be associated with sleep quality (23). In a study (24), it has been reported that people who focus COVID-19 disease for 3 hours or more had significantly higher depression scores. Uncertain prognoses and treatment, loss of relatives, being unemployed indefinitely and financial losses may contribute to emotional distress and increase the risk for psychiatric diseases (25). Sleep interruption is one of the most common symptom of depression (26). As a finding supporting the literature, hospital depression and anxiety scores of our patients were high and significantly associated with the poor sleep quality. Not only depression and anxiety, also musculoskeletal disorders, obesity and other chronic diseases can cause sleep disorders (27).

Studies of large cohorts have shown that sleep quality in smokers is significantly reduced compared to non-smokers $(28,29)$. There was no significant effect of smoking on sleep quality in our COVID-19 patients.

In a study from Brazil, it was reported that monthly income, occupation, gender, age and marital status had effects on sleep quality (30). But, we did not find any significant effect of gender, age and marital status on sleep quality in our study. Sleep has an important role for human immune system and metabolism (31). Sleep disturbance impairs immune responses and activates inflammation (32). Shorter sleep time or poor sleep quality could increase the risk of upper respiratory infections (33). Septic patients with impaired sleep integrity have been reported with higher mortality rates (34). In a recent study, it was reported that poor sleep quality was associated with the recovery time of lymphopenia and the need for intensive care in hospitalized COVID-19 patients (35).

Laboratory parameters associated with inflammation (CRP) and coagulation (D-dimer) were higher whereas the WBC and lymphocyte counts and albumin were lower in non-severe COVID-19 pneumonia patients in our study. The prolongation of hospital stay in our patients with severe inflammation and lymphopenia may be due to poor sleep quality.

Dyspnea was associated with sleep quality significantly in our study. As a result of increased airway resistance, nocturnal bronchoconstriction occurs, which is due to normal circadian changes in the airways (36). In addition, decreased intercostal muscle activity during sleep may increase the symptoms of the patient with COVID-19 pneumonia. Poor sleep quality in patients with pneumonia; it can also be due to many reasons such as drugs used for treatment, disease symptoms, comorbidities, anxiety and depression. However, there was no association between sleep quality and comorbidities in our patients. Respiratory disturbances during sleep may be associated with oxygen desaturation and development of hypoventilation.
This may be the reason of the negative significant correlation between oxygen saturation and sleep quality in our study. Some variables might interact with each other in our study. The disease severity might increase stress, stress might increase anxiety and depression. Increased depressive mode might lead to poor sleep quality. The poor sleep quality might delay the recovery time since sleep has an important role in immune system. There was no interactions between sleep quality and age, gender, BMI, alcohol or smoking. This result might be due to the small number of patients included in the study. We collected the data of the patients who could cooperate with us and finish the questionnaire. The small size of qualitative samples is a limitation of this research.

\section{Conclusion}

The findings from this study showed that anxiety and depression of the hospitalized patients with COVID-19 pneumonia were at high levels, while the sleep quality was low. Both anxiety and depression had effects on sleep quality. This study showed a significant association between poor sleep quality and the prolonged hospitalization time. Disease severity was a significant risk factor for sleep quality. Our study was a cross-sectional one. To find out more information about patients' mental distress and sleep quality changes during and after hospitalization, future studies may contain the follow-up of patients.

\section{Ethics}

Ethics Committee Approval: This study was performed in accordance with the Declaration of Helsinki and was approved by the Muğla Sıtkı Koçman University Human Research Ethics Committee (protocol number: 200179, decision no: 150).

Informed Consent: All patients provided signed informed consent to participate in the study.

Peer-review: Internally peer-reviewed.

\section{Authorship Contributions}

Concept: Ö.O.T., Design: Ö.O.T., Data Collection or Processing: Ö.O.T., U.T., F.A., A.F.A., Analysis or Interpretation: Ö.O.T., U.T., S.G., Writing: Ö.O.T.

Conflict of Interest: No conflict of interest was declared by the authors.

Financial Disclosure: The authors declared that this study received no financial support.

\section{References}

1. Taylor C, Lillis C, Prisecilla LM. Fundamentals of the Nursing. Philadelphia, JB Lippincott Company, 2001;1013-36.

2. Black J, Hawks HJ, Keene MA. Foundations of Medical Surgical Nursing. 6th ed. England, Mosby, 2003;431-43.

3. Alessi CA, Martin JL, Webber AP, Alam T, Littner MR, Harker JO, Josephson KR. More daytime sleeping predicts less functional recovery among older people undergoing inpatient post-acute rehabilitation. Sleep 2008;31:1291-300.

4. Martin JL, Fiorentino L, Jouldjian S, Mitchell M, Josephson KR, Alessi CA. Poor self-reported sleep quality predicts mortality within one year of inpatient post-acute rehabilitation among older adults. Sleep 2011;134:1715-21. 
5. Drouot X, Cabello B, d'Ortho MP, Brochard L. Sleep in the intensive care unit. Sleep Med Rev 2008;12:391-403.

6. Wu KK, Chan SK, Ma TM. Posttraumatic stress, anxiety, and depression in survivors of severe acute respiratory syndrome (SARS). J Traumatic Stress 2005;18:39-42.

7. Buysse DJ, Reynolds CF 3rd, Monk TH, Berman SR, Kupfer DJ. The Pittsburgh Sleep Quality Index: a new instrument for psychiatric practice and research. Psychiatry Res 1989;28:193-213.

8. Zigmond AS, Snaith PR. The Hospital Anxiety and Depression Scale. Acta Psychiatr Scand 1983;67:361-70.

9. Huang C, Wang Y, Li X, Ren L, Zhao J, Hu Y, Zhang L, Fan G, Xu J, Gu X, Cheng Z, Yu T, Xia J, Wei Y, Wu W, Xie X, Yin W, Li H, Liu M, Xiao Y, Gao H, Guo L, Xie J, Wang G, Jiang R, Gao Z, Jin Q, Wang J, Cao B. Clinical features of patients infected with 2019 novel coronavirus in Wuhan, China. Lancet 2020;395:497-506.

10. Liguori C, Pierantozzi M, Spanetta M, Sarmati L, Cesta N, lannetta $M$, Ora J, Mina GG, Puxeddu E, Balbi O, Pezzuto G, Magrini A, Rogliani $P$, Andreoni M, Mercuri NB. Subjective neurological symptoms frequently occur in patients with SARS-CoV2 infection. Brain Behav Immun 2020;88:11-6.

11. Guo Q, Zheng Y, Shi J, Wang J, Li G, Li C, Fromson JA, Xu Y, Liu X, Xu H, Zhang T, Lu Y, Chen X, Hu H, Tang Y, Yang S, Zhou H, Wang $X$, Chen $H$, Wang Z, Yang Z. Immediate psychological distress in quarantined patients with COVID-19 and its association with peripheral inflammation: a mixed-method study. Brain Behav Immun 2020;88:17-27.

12. Zhang J, Xu D, Xie B, Zhang $Y$, Huang $H$, Liu $H$, Chen $H$, Sun $Y$, Shang Y, Hashimoto K, Yuan S. Poor-sleep is associated with slow recovery from lymphopenia and an increased need for ICU care in hospitalized patients with COVID-19: A retrospective cohort study. Brain Behav Immun 2020;88:50-8.

13. Ağargün MY, Kara $H$, Anlar Ö. Pittsburgh Uyku Kalitesi Indeksi'nin Geçerliği ve Güvenirliği. Türk Psikiatri Dergisi 1996;7:107-15.

14. Aydemir Ö. Hastane Anksiyete ve Depresyon Ölçeği Türkçe formunun geçerlilik ve Güvenilirliği. Türk Psikiyatri Dergisi 1997;8:280-7.

15. Özvurmaz S, Asgarpour H, Güneş Z. Yaşılılarda Uyku Kalitesi ve Yaşam Kalitesi Arasındaki İlişki: Kesitsel Bir Çalışma. Medical Sciences 2018;13:72-9.

16. Cölbay M, Yüksel S, Fidan F, Acartürk G, Karaman O, Unlü M. Evaluation of the hemodialysis patient with Pittsburgh sleep quality index. Tuberk Toraks 2007;55:167-73.

17. Pellatt GC. The nurse's role in promoting a good night's sleep for patients. Br J Nurs 2007;16:602-5.

18. Yilmaz M, Sayin Y, Gurler H. Sleep quality of hospitalized patients in surgical units. Nurs Forum 2012;47:183-92.

19. Salfi F, Amicucci G, Corigliano D, D'Atri A, Viselli L, Tempesta D, Ferrara M. Changes of evening exposure to electronic devices during the COVID-19 lockdown affect the time course of sleep disturbances. Sleep 2021;44: zsab080. doi: 10.1093/sleep/zsab080

20. Walker MP. The role of sleep in cognition and emotion. Ann NY Acad Sci 2009;1156:168-97.
21. Zohar D, Tzischinsky O, Epstein R, Lavie P. The effects of sleep loss on medical residents' emotional reactions to work events: A cognitiveenergy model. Sleep 2005;28:47-54.

22. Franceschini C, Musetti A, Zenesini C, Palagini L, Scarpelli $S$, Quattropani MC, Lenzo V, Freda MF, Lemmo D, Vegni E, Borghi L, Saita E, Cattivelli R, De Gennaro L, Plazzi G, Riemann D, Castelnuovo G. Poor sleep quality and its consequences on mental health during the COVID-19 lockdown in Italy. Front Psychol 2020;11:574475.

23. Reeth OV, Weibel L, Spiegel K, Leproult R, Dugovic C, Maccari S. Interactions between stress and sleep: From basic research to clinical situations. Sleep Med Rev 2000;4:201-19.

24. Huang Y, Zhao N. Generalized anxiety disorder, depressive symptoms and sleep quality during COVID-19 outbreak in China: A web-based cross-sectional survey. Psychiatry Res 2020;288:112954.

25. Pfefferbaum B, North CS. Mental Health and the Covid-19 Pandemic. N Engl J Med 2021;383:510-2.

26. Tsuno N, Besset A, Ritchie K. Sleep and depression. J Clin Psychiatry 2005;66:1254-69.

27. Chang KJ, Son SJ, Lee Y, Back JH, Lee KS, Lee SJ, Chung YK, Lim $\mathrm{KY}$, Noh JS, Kim HC, Koh SH, Roh HW, Park MA, Kim JJ, Hong CH. Perceived sleep quality is associated with depression in a Korean elderly population. Arch Gerontol Geriatr 2014;59:468-73.

28. Riedel BW, Durrence HH, Lichstein KL, Taylor DJ, Bush AJ. The relation between smoking and sleep: the influence of smoking level, health and psychological variables. Behav Sleep Med 2004;2:63-78.

29. Wetter DW, Young TB. The relation between cigarette smoking and sleep disturbance. Prev Med 1994;23:328-34.

30. Lima MG, Barros MBA, Szwarcwald CL, Malta DC, Romero DE, Werneck AO, Souza Júnior PRB. Association of social and economic conditions with the incidence of sleep disorders during the COVID-19 pandemic. Cad Saúde Pública 2021;37:e00218320. doi: 10.1590/0102-311X00218320

31. Besedovsky L, Lange T, Haack M. The Sleep-Immune Crosstalk in Health and Disease. Physiol Rev 2019;99:1325-80.

32. Haack M, Sanchez E, Mullington JM. Elevated inflammatory markers in response to prolonged sleep restriction are associated with increased pain experience in healthy volunteers. Sleep 2007;30:1145-52.

33. Cohen S, Doyle WJ, Alper CM, Janicki-Deverts D, Turner RB. Sleep habits and susceptibility to the common cold. Arch Intern Med 2009;169:62-7.

34. Huang YH, Jiang D, Huang JT. SARS-CoV-2 Detected in Cerebrospinal Fluid by PCR in a Case of COVID-19 Encephalitis. Brain Behav Immun 2020;87:149. doi: 10.1016/j.bbi.2020.05.012

35. Zhang J, Xu D, Xie B, Zhang $Y$, Huang $H$, Liu $H$, Chen $H$, Sun $Y$, Shang $Y$, Hashimoto K, Yuan S. Poor-sleep is associated with slow recovery from lymphopenia and an increased need for ICU care in hospitalized patients with COVID-19: A retrospective cohort study. Brain Behav Immun 2020;88:50-8.

36. Gay PC. Chronic obstructive pulmonary disease and sleep. Respir Care 2004;49:39-51. 